\title{
Small-scale agricultural product marketing innovation through BUMDes and MSMEs empowerment in coastal areas
}

\author{
Almasdi Syahza ${ }^{a^{*}}$, Enni Savitri $^{\mathrm{b}}$, Brilliant Asmit ${ }^{\mathrm{c}}$ and Geovani Meiwanda ${ }^{\mathrm{d}}$
}

anstitute for Research and Community Service (LPPM), Universitas Riau, Pekanbaru 28293, Indonesia

${ }^{b}$ Faculty of Economics and Business, Riau University, Pekanbaru 28293, Indonesia

${ }^{c}$ Economic Education Program, Riau University, Pekanbaru 28293, Indonesia

${ }^{d}$ Faculty of Social and Political Science, Riau University, Pekanbaru 28293, Indonesia

\section{H R O N I C L E}

Article history:

Received: January 5, 2021

Received in revised format:

January 262021

Accepted: March 30, 2021

Available online:

March 30, 2021

Keywords:

Rural economy

Marketing of agricultural

products

BUMDes

MSMES

\section{A B S T R A C T}

\begin{abstract}
A region's economic growth depends on the development policies based on the wealth determined from the potential of human, institutional and local resources. Furthermore, the development needs to link primary sectors with future processing to increase agricultural products' added value and marketing competitiveness. This study develops an innovative marketing model in agricultural products for small-scale farmers through village-owned enterprises (BUMDes) and micro, small, and medium enterprises (MSMEs) empowerment in coastal areas. One way of realizing this program is by building agribusiness and agro-industry partnerships that are well-planned and associated with other economic sectors' development. The partnership involves community economic institutions, including BUMDes, credit institutions, farmer entrepreneurs, as well as Micro, Small, and Medium Enterprises. BUMDes is a rural-based business with a legal entity managed by the village government to create added value for the community's agricultural products. Together with MSMEs, these businesses need to support the agribusiness subsystem's development, including trading in agricultural production facilities and business activities. Furthermore, they need to promote agricultural production, support services, a source of market information for rural communities, the main actors of appropriate technology for agricultural products.
\end{abstract}

\section{Introduction}

Several obstacles are likely to be encountered in the future development of agribusiness and agro-industry. The obstacles faced by small-scale farmers in coastal areas include limited agricultural capital and access to marketing, which is one of the critical production factors in small-scale farming in coastal areas. This is because farmers increase working capital for their agricultural business through rural institutions. According to Grashuis (2018), the farmers' cooperatives in the US improve financial performance by emphasizing sales and operating costs of bargaining power, product differentiation, and economies of scale. Previous research has demonstrated, farmers' capital ownership is still relatively small because it comes from previous farming income (Syahza et al., 2018). Therefore, agricultural products' competitiveness could increase the farming capital of rural farmers (Pigatto et al., 2020). Previous research has shown problems of land availability and soil fertility are common among small-scale farmers. As a production factor, soil fertility in coastal areas is a major problem since the land is made of peat soil with a $\mathrm{PH}$ of 4, meaning that limited land is useful. Changes in farming behavior significantly determine land use. The main problem for small-scale farmers is limited land ownership since the arable land in rural areas is less than 0.35 ha Syahza et al. (2020a). In line with this, Geoghegan et al. (2017), Lakitan (2019) stated that the government needs to

* Corresponding author.

E-mail address: almasdi.syahza@lecturer.unri.ac.id (A. Syahza) 
distribute land fairly to rural small-scale farmers since they have limited and less fertile land. The coastal area is a wetland dominated by seawater as the primary means of transportation, hindering the procurement and distribution of production facilities. These facilities are essential in production for small-scale farmers to obtain satisfactory results. Also, they need to be planned for convenient use according to the farmers' needs. The limited ability of small-scale farmers to master technology slows down intensive production. This is because technology needs to be integrated into various production factors and facilities. Farmers acting as managers and workers in their agricultural activities must be knowledgeable and skilled in using various farming inputs to increase productivity and efficiency. Small-scale farmers are weak to determine the price level, and they need support from rural institutions. This is because institutions are vital platforms in the farming community concerning information delivery and farmer inspiration. Therefore, small-scale agricultural institutions are needed to strengthen the bargaining power of farmers. On the other hand, farm-level institutions drive rural agricultural development, as seen from the farmer group superiority in facilitating the coordination, extension, and provision of technology packages. According to Adanu (2017), potential institutional changes address specific rural-economic development challenges based on the business environment. Agricultural industrialization is necessary for strengthening the people's economy. Hence, a populist economy is achieved through the institutional development of agricultural businesses. This development needs to create the added value from every economic chain in agricultural industrialization.

Another factor that slows down rural economic development among small farmers is the limited human resources in the agricultural sector. The average education level of small-scale farmers in Indonesia is junior high school, a situation largely influenced by the available human resource quality. As a result, these two factors are used as indicators in assessing the problems existing in agricultural activities. Farmers are human resources with an essential role as workers and managers in determining a farming activity's success. The rural agricultural products could be developed by creating superior and reliable commodities, increasing agricultural products' added value, and creating marketing systems. Furthermore, the products could be developed through providing transportation and distribution facilities, developing partnerships, and restructuring agricultural and agro-industrial systems and institutions. Marketing and brand factors are very important because the added value of the agro-industry is measured from consumer perceptions. Agro-industry contributes significantly when a higher perception is provided through value creation and complemented with the right marketing applications.

Furthermore, Surya et al. (2021), the increase in the productivity of the regional economic sector has an impact on the development of agropolitan areas based on rural agribusiness, in a synergy, there will be an increase in community income and regional economy. The regional development of superior commodities creates business opportunities for rural communities. Previous research has demonstrated, business opportunities are a source of additional income for the communities that are able to use this potential to develop real business activities. The community's ability to utilize existing opportunities is influenced by its management of resources and the development of a viable business (Syahza et al., 2018). In developing countries, the agricultural sector's development depends on the State Revenue and Expenditure Budget and is influenced by political, economic, social, and technological factors. This means that the agricultural sector's development is one important area that maintains a country's socio-economic stability. According to Veldkamp et al. (2009), agricultural innovation programs have 5 main characteristics. The first characteristic concerns sustainable development with dynamic system properties. Secondly, sustainable development requires system innovation. Third, agricultural innovation is a process of renewal to increase added value. Fourth, innovation encourages the participation of farmers and policymakers related to agricultural progress. Fifth, the innovation program requires the collaboration of various parties to increase the added value of agricultural products.

The development of commodity diversity at the farm level with inadequate land ownership and high farming risks needs local government support. Hence, local governments must ensure that agricultural commodities are seeded to become superior by increasing their commercialization. Improved commercialization is achieved through increasing productivity and outcome quality, expanding the planting area using specific location technology, applying special agricultural tools and machinery for product processing, and increasing public awareness promotion. According to Zinchuk et al. (2019), progressive economic change does not produce the same results, necessitating the need for a humancentric rural development model, an observation supported by Berlanga (2012). Many studies have been conducted on agricultural sector development and product innovation, including Fu et al. (2011), Pehrsson (2016), Lahham (2016), Zhou et al. (2016), Naknaen (2017), Devaux et al. (2018), Huang and Liang (2018), Barzola and Dentoni (2020), Liu and Zeinaly (2020). Studies on institutional empowerment and the rural economy include Hendriani (2018), Indarti, S. (2018), Syahza (2019), Syahza and Asmit (2019), Caska and Indrawati (2019), Syahza et al. (2020b), and Kamaliah (2020). Furthermore, studies on MSMEs need to exploit innovation's power to maintain competitiveness Cano-Kollmann et al. (2018); Parida et al. (2012). Also, the adoption of innovations in the agricultural sector and MSMEs overcome the scarcity of internal resources and competencies (Bogers et al., 2018; Di-Pietro et al., 2018; Van Hemert et al., 2013; Wynarczyk et al., 2013; Lichtenthaler, 2011).

Strategies to improve the welfare of small-scale farming communities need to build agribusiness-based partnerships since there are breakthroughs to increase the added value of agricultural products. This study identifies the factors supporting agribusiness-based rural economic development to find an innovative model of marketing agricultural products for smallscale farmers in coastal villages. 


\section{Research Methods}

The study used a survey with the Descriptive Research method, focusing on the development of economic institutions through village-owned enterprises (BUMDes), as well as micro, small, and medium enterprises (MSMEs) in Riau Province. This survey method was used with a gradual location determination in the area or district. The location chosen is a potential area for development based on commodity superiority, farming, as well as village and human resource potential. A stratified cluster sampling technique was used to obtain a sample representing each selected area. This method considers that the research locations are scattered based on BUMDes and MSMEs' characteristics as various research objects. Purposive sampling was employed on each cluster based on the rural businesses engaged in agriculture (agribusiness) and the existence of micro, small and medium enterprises that have conducted the post-harvest process (agro-industry). The research used primary data obtained from business people in MSMEs and BUMDes, community leaders, and rural bureaucracy. Data from the rural bureaucracy and community leaders were about existing resource potentials, the community's economy, superior and supporting commodities, farming diversification, and ownership of production factors. Furthermore, primary data were sourced from trade system institutions directly related to the community economy. On the other hand, secondary data were obtained from literature reviews and related agencies that supported this research. Data were collected using the Rapid Rural Appraisal (RRA) method, which is a participatory approach to obtain general information and field assessments in a short time (Townsley, 1996). Respondent information was based on the interview guidelines prepared by the research team. The RRA method focused on farmer participation in achieving sustainable agricultural development (Ison and Ampt,1992) and is widely used by researchers, including Uddin and Anjuman (2013), Mustanir and Lubis (2017), Sandham et al. (2019). The data sources were reviewed in case the required information was lacking. The descriptive data were analyzed quantitatively and qualitatively through socio-economic conceptual approaches based on regional conditions, superior rural commodities, socio-economy, and government policies. It is hoped that this research develops a model of agricultural product marketing innovation for small-scale farmers in coastal areas.

\section{Results and Discussion}

\subsection{Agricultural Product Marketing Constraints}

The marketing of small-scale agricultural products in coastal areas plays a dual role. This includes price transfer between producers and consumers and a physical transmission from producers to the consumers. However, in playing these two roles, small-scale farmers face various obstacles in marketing agricultural products. According to Mariyono et al. (2019), the marketing channels for vegetable agriculture in Indonesia are quite complex and relatively long. Hence, the farmers choose a particular channel because of their business circumstances and limited knowledge. Moreover, distance and agreement between farmers and traders limit rural farmers from choosing the desired marketing channel, affecting their income. Previous research has demonstrated, the obstacles in marketing rural agricultural products include production continuity and low-quality products, insufficient market information, and fluctuating prices. Other obstacles are unclear marketing networks, inadequate markets, long marketing channels, and low bargaining power (Syahza \& Indrawati, 2010; Syahza et al., 2018),

\section{Production continuity}

One cause of the problems in marketing agricultural products is the small production volume due to the small-scale business. Farmers conduct agricultural business activities on land less than $0.35 \mathrm{ha}$. On the contrary, agricultural businesses with export products, such as oil palm, rubber, coconut, sago, have average land ownership of around 2-5 ha per patriarch. Furthermore, the technology used is still simple and has not been managed intensively, resulting in low and seasonal production. This causes seasonal and surplus production, reducing the selling price of these products. On the other hand, during the off-season, the available products are limited, and the selling price soars, forcing the collecting traders to provide sufficient capital to buy the products. Moreover, the product may be unavailable occasionally, forcing importation from other regions. Third, the farming businesses are scattered, making it difficult for traders to collect the products. Also, farmers try to find a planting location with suitable soil and climatic conditions that support crop cultivation. This makes traders take longer to collect and transport the products from farmers, increasing marketing costs. Fourth, heavy and perishable agricultural products require much space. As a result, certain traders are unwilling to sell agricultural products because they are economically less profitable than industrial products (agro-industry). According to Gras and Hernández (2014), agricultural production is driven by economic and institutional changes, leading to economic concentration. Hence, it is necessary to increase farmers' capital and resources in expanding agricultural scale and production. According to Shikur (2020), government policies increase agricultural commodities through technical assistance and irrigation. As a result, the implementation of these policies greatly affects agricultural productivity.

\section{Low production quality}

The low-quality production is caused by less intensive handling of activities from pre-harvest to post-harvest activities, including standardization and grading, where quality is determined. Standardization streamlines the loading and unloading process and saves space, while grading eliminates the need for inspection. Furthermore, grading facilitates price comparisons, reduces fraudulence, and accelerates the buying and selling process. Therefore, these two activities protect goods from damage, reducing transportation and storage costs. On the other hand, the production quality is improved by applying appropriate technology for small-scale farmers since innovation needs to be a continuous process. According to Indrawati et 
al. (2020), the 5 factors inhibiting rural technological innovation are government support, human resource quality, funding, economic conditions, and business partners. However, the biggest limiting factor is funding technological innovation, an observation that aligns with Pereira et al. (2020), which stated that innovation and technology are essential in leveraging the agricultural sector. These two activities are difficult to perform due to the production of perishable agricultural products. The product's quality may change after arriving at the destination, shrinkage or damage during transportation, handling, and storage. This causes products previously classified based on quality and demand to change and become rejected or purchased at a lower price.

\section{Lack of market information}

Market information helps farmers determine the type of production, market opportunities to get the best price and profit. Accurate market information will reduce risks for rural farmers, allowing traders to operate with low marketing margins, benefiting themselves, producers, and consumers. On the contrary, limited market information is related to remote farming locations, limited knowledge and market analysis skills. Furthermore, farmers' formal education is still very low, resulting in inefficient digestion or analysis of information sources. This causes farming to be conducted without careful planning, resulting in traders with no knowledge about market macro conditions. According to Ahmed and Mesfin (2017), agricultural institutions provide welfare for small-scale farmers. Moreover, membership in agricultural enterprises strongly influences the bargaining power of agricultural products. Alho (2015) showed that tighter competition for raw materials among farmers increases pressure on traders to obtain optimal raw materials.

\section{Price fluctuation}

The prices of agricultural products fluctuate depending on changes in supply and demand. The price fluctuations could be short-term, such as monthly, weekly, daily, or long-term. Agricultural market-type contracts cannot maximize farmer income because farmers cannot avoid market risks and bargaining (Sun and Li, 2019). Furthermore, market demand changes sometimes affect the prevailing prices of perishable agricultural products. This is especially felt in traditional markets both in rural and urban areas. Moreover, the seasonal price changes depending on the product's abundance or scarcity make it difficult for farmers and traders to plan production and estimate demand, respectively.

\section{Lack of clear marketing network}

Producers and traders from rural areas have difficulty finding new markets for their agricultural products. This is because they are not included in the marketing network and the limited knowledge of the applicable system. As a result, the resulting production experiences obstacles in expanding the marketing network. In general, the marketing system between farmers and intermediate traders has family agreements with strong ties, making it difficult for other parties to know. According to Sathapatyanon et al. (2018), the main problems facing small-scale farmers are the marketing of agricultural products, market uncertainty, increased production costs, and weak marketing networks. Iba and Lilavanichakul (2020) show that the development of marketing channels requires farmers to allocate family labor efficiently, have marketing skills, manage marketing chains, and farmer cohesiveness. Marketing skills through and mastery of digital technology enable farmers to expand markets and build networks.

\section{Inadequate market}

The intended market insufficiency relates to fixing prices and payments. There are 3 ways to determine the selling price of agricultural products, including the prevailing price, bargaining, and wholesale. Based on prevailing prices, marketing depends on supply and demand following market mechanisms. Pricing through bargaining is familial, implying that a transaction is conducted when an agreement is reached between the seller and the buyer. On the other hand, wholesale marketing practices take place because of the farmers' weak financial condition. This takes place through the intermediary traders buying products by giving down payments to farmers to guarantee the product desired by the trader concerned. As a result, farmers did not have the opportunity to sell the products to other traders. According to Devaux et al. (2018), opportunities arising from new and developing markets for agricultural products are derivative product innovations that build a marketing chain between small-scale farmers and capital owners.

\section{Marketing channel length}

The length of a marketing channel causes high marketing margins and is partly spent as profit for traders, reducing the farmers' share and increasing the consumers' costs. Moreover, the length is indicated by a large number of intermediary traders to be passed from farmers to the final consumer. Field observations show that farmers carry out two marketing channels. First, about $75 \%$ of small-scale farmers market their agricultural products through collectors, wholesalers, and processing factories (agro-industry). The second route, the remaining 25\%, is sold to wholesalers and processing factories. A large number of farmers sell their crops through the first route because traders go directly to farmers. On the contrary, selling through the second channel involves traders waiting for the farmers that face risks related to the perishability of their agricultural products. 


\section{Low bargaining power}

The ability of farmers to offer their products is still limited due to insufficient capital, making products to be sold at low prices, while the traders receive the highest profits. This capital limitation is related to two factors, the first being the mental attitude of farmers that happily receive loans from intermediaries. This results in the farmers' dependence on intermediary traders, placing them in a weak position. Second, the government credit facilities have not been optimally utilized. This is due to insufficient knowledge of the borrowing procedure, the credit institution's distant location, and the inability to meet the stipulated requirements. Furthermore, farmers are worried about risks and uncertainties during production, and they cannot return the credit. This shows that their knowledge and understanding of credit issues are limited, and their trust level is low. One of the institutional functions of rural farmers is increasing the ability to bargain agricultural products. Institutions must provide market information and locations. Courtois and Subervie (2015) showed that market information service benefits farmers, improve efficiency, and increases agricultural product prices. Furthermore, Velázquez and Buffaria (2017) showed that market information services at the smallholder level offset inequalities along the marketing chain and increase efficiency, farmer income, and consumer welfare. Previous research has demonstrated, the relatively low education level of farmers affects agricultural technology absorption, making it difficult for them to develop and accept agricultural reforms. Additionally, farmers lack adequate training facilities, resulting in improper product handling from pre-harvest to post-harvest and marketing. On the other hand, farmer development has mainly focused on cultivation rather than marketing practices, limiting their marketing knowledge. Therefore, the marketing subsystem is weak and needs to be included in agribusiness (Syahza \& Indrawati, 2010). Choosing market type and secondary income contracts increases the income of risk-seeking farmers (Sun \& $\mathrm{Li}, 2019)$. Similar conditions of the limited ability of intermediary traders are experienced in urban areas. This is observed from the inability to negotiate with modern trade and business partners, such as supermarkets, restaurants, and hotels. The modern market is an excellent opportunity for agricultural products because it provides high added value Engotoit et al. (2016). However, there is a significant positive relationship between performance expectations and behavioral intention to use mobilebased communication technology to access and disseminate agricultural information. Hence, farmers need to use technology to obtain market information for agricultural products in the future.

\subsection{Agricultural Product Marketing Innovations in Rural Areas}

A new paradigm is needed to overcome the problems experienced by farmers in marketing agricultural products. One alternative solution is to empower rural economic institutions, including Village-Owned Enterprises (BUMDes), a rural-based business with a legal entity managed by the village government. Therefore, the village government is capable of establishing the businesses according to the village's needs and potential. The establishment is regulated by village regulations, and the businesses' management consists of village government and local communities. BUMDes are essential in the development of small-scale agribusiness enterprises. Small agribusiness cannot develop without BUMDes, which are associated with big entrepreneurs. Moreover, they are essential in improving the rural socio-economic standards by utilizing the potential and absorption of labor and directing benefit because it aligns with the village community's life. Moreover, the village economy develops because BUMDes is formed based on rural needs. According to Brown et al. (2011), the marketing system's modernization is essential for smallholders to access the available premium prices and increase international competitiveness. The empirical results show that organizational agility is a mediator in conveying the positive influence of e-commerce capabilities on improving agricultural business performance through product marketing ( $\mathrm{Li}$ et al., 2020). BUMDes is a rural business entity and a full implementer of the agribusiness subsystem. Moreover, it functions as an intermediary trader and a marketing agent of agricultural products of its members. At BUMDes, product sorting, processing, packaging, labeling, and storage are conducted according to market demands and needs. The business entity plays a role as market information media related to opportunities and purchasing power, as well as price developments. BUMDes need to create market opportunities for agricultural products through this information, enabling farmers to carry out their farming activities because their products are guaranteed accommodation. This encourages member participation and supports the BUMDes business, resolving the problems faced by farmers. The agribusiness-based agricultural product marketing innovation is seen in Fig. 1.

BUMDes invest in transportation and rural agricultural processing machines (agro-industry) on behalf of members. This means that each member owns BUMDes asset shares, promoting the concept of agroestate in rural areas (Syahza, 2007). Moreover, BUMDes provide credit from institutions and entrepreneurs, and lending is based on the agricultural enterprises that develop superior commodities and have market opportunities. The rate of return on credit by farmers is determined by reducing sales of agricultural products to BUMDes. According to Gaudreau, there is a tendency for relatively few agribusiness activities to be managed by multinational companies. On the other hand, the supply of local food movements is still limited and requires capital owners' support to develop the agricultural sector. Hence, the concept of agribusiness must involve various parties to build an integrated system (Gaudreau, 2019). Surya et al. (2021). Moreover, the concept of agricultural system integration needs to exist in the development of agropolitan areas based on the balance of ecosystems and local economic growth in rural areas. Barzola and Dentoni (2020) stated that proactive farmers significantly encourage their low-level product innovation, while entrepreneurial intentions are not essential for innovation. 


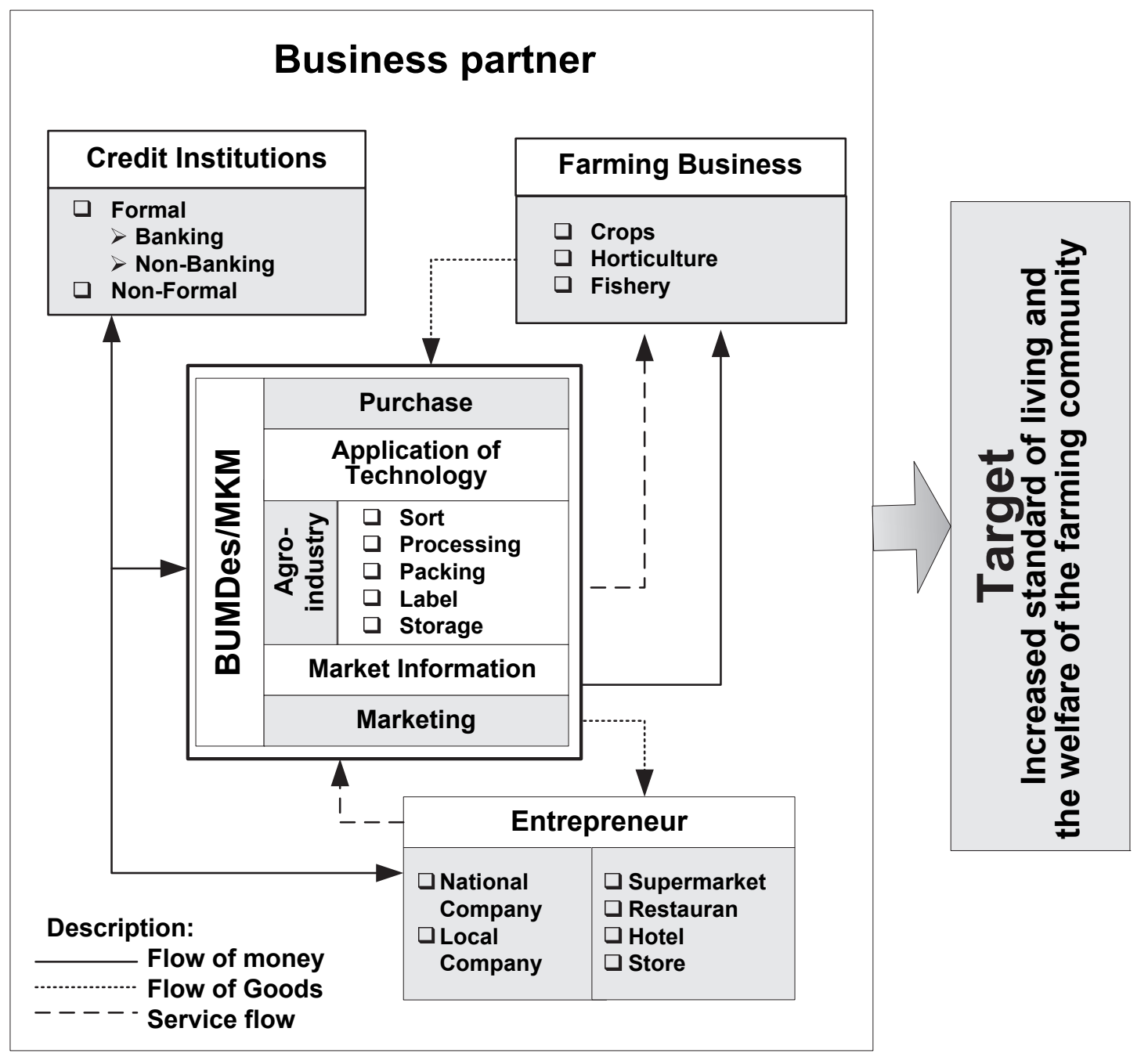

Fig. 1. Agribusiness-Based Agricultural Product Marketing Innovation Model in Coastal Areas

The activities of this business unit provide a multiplier effect on people's economy. As a business unit, agribusiness creates opportunities in economic activities, increasing the rural communities' income and improving their welfare. BUMDes and MSMEs are also crucial in developing alternative solutions to agricultural problems, such as providing credit and forming joint capital through savings. Moreover, they provide production facilities, integrated pest control, agro-industry players, and marketing agricultural products. Second, BUMDes and MSMEs provide business training and guidance to farmers. Third, farmers need to be organized to strengthen their bargaining position in facing competition and forge partnerships with other parties.

In the current globalization era and future trade liberalization, the government's role is getting smaller, even the import tax and subsidy policies would be eliminated in due course. Hence, the private sector's participation, including large companies, is needed to fill and complement various government programs. For instance, entrepreneurs in a strong position could help weak farmers through partnership networks. According to Bissonnette, the development of the agribusiness concept increases the added value and small-scale farmer's income. However, the greatest challenge for agribusiness actors is to improve the governance function and regulatory framework for small-scale farmers and wage workers in the agricultural sector (Bissonnette, 2016). In line with Savitri and Syahza (2019), Savitri et al. (2020), the small and medium enterprises sector related to most Indonesians' economic life is vital in strengthening the national economy's structure. On the other hand, business performance is influenced by adaptation strategies, entrepreneurial orientation, and government policies. According to Huang and Liang (2018), traditional farmers participate effectively in modern agriculture through cooperatives, determining their central position in the agricultural organization system. Kireyenka stated that the national food security approach is highlighted in terms of agricultural conditions, targets, and objectives. Therefore, agricultural development must consider national priorities in production, domestic consumer markets, and foreign trade (Kireyenka, 2019). 
This relationship provides various benefits to farmers, such as technology transfer and provision of inputs. Hence, farmers compete with other products using superior inputs and technology and quickly obtain market information and opportunities, access capital, and market certainty for agricultural products.

\section{Conclusion}

Several obstacles can be faced in the development of agribusiness and agricultural systems based on agro-industry in coastal areas. These constraints are related to weak capital structure and accessibility, limited land and soil fertility, as well as the procurement and distribution of production facilities. Another problem is the limited mastery of technology, weak agricultural institutions, limited management skills, as well the limited number of workers who are interested in doing business in the agricultural sector, especially in coastal areas. On the other hand, farmers face obstacles in marketing agricultural products, including sustainable production, the length of the marketing channel, and insufficient market. Other challenges include lack of market information, low bargaining power, price fluctuation, low production quality, unclear marketing network, and lowquality human resources. Strategic policies are needed to increase rural communities' income and welfare to achieve populist economic development in the agricultural sector. Moreover, agribusiness and agro-industry-based agricultural programs must be strategic and associated with other economic sectors' development. One solution is agricultural product marketing innovation for small-scale farmers since an innovative model of marketing agricultural products improves rural communities' welfare. However, this innovation must increase communities' welfare through farmers' income because it is built in partnership. This business partnership involves community economic institutions, including Village-Owned Enterprises (BUMDes), credit institutions, farmer entrepreneurs, as well as micro, small and medium enterprises (MSMEs). BUMDes is a rural-based business with a legal entity managed by the village government to create added value for the rural community's agricultural products. On the other hand, agribusiness-based partnerships support the agribusiness subsystem's development through trade in agricultural production facilities, business activities, and product processing. Moreover, the partnership support services are expected to be able to provide market information for rural farmers and adopt appropriate technology for agricultural advancement.

\section{Acknowledgement}

This article concludes the research on the management and potential increase of peatlands to accelerate communities' economies in the coastal areas of Riau Province Contract Number: 592/UN.19.5.1.3 / PP / 2018. The author thanks the Riau University Research and Community Service Institute (LPPM) for providing the opportunity and funding this research. Hopefully, this work is useful for the development of science and the advancement of education in Indonesia.

\section{References}

Adanu, K. (2017). Institutional change and economic development: a conceptual analysis of the African case. International Journal of Social Economics, 44(4), 547-559. https://doi.org/10.1108/IJSE-02-2014-0022

Ahmed, M.H., \& Mesfin, H.M. (2017). The impact of agricultural cooperatives membership on the wellbeing of smallholder farmers: empirical evidence from eastern Ethiopia. Agricultural and Food Economics, 5(6). https://doi.org/10.1186/s40100-017-0075-z

Alho, E. (2015). Farmers' self-reported value of cooperative membership: evidence from heterogeneous business and organization structures. Agricultural and Food Economics, 3(23). https://doi.org/10.1186/s40100-015-0041-6

Barzola Iza, C.L., \& Dentoni, D. (2020). How entrepreneurial orientation drives farmers' innovation differential in Ugandan coffee multi-stakeholder platforms. Journal of Agribusiness in Developing and Emerging Economies, 10(5), 629650. https://doi.org/10.1108/JADEE-01-2020-0007

Berlanga, H.M.R. (2012). Transnational agribusiness capital and land market dynamics in Mexico. Canadian Journal of Development Studies, 33(4), 529-551. https://doi.org/10.1080/02255189.2012.747429

Bogers, M., Chesbrough, H., \& Moedas, C. (2018). Open innovation: research, practices, and policies. California Management Review, 60(2), 5-16. https://doi.org/10.1177/0008125617745086

Brown, C., Waldron, S., \& Longworth, J. (2011). Specialty products, rural livelihoods and agricultural marketing reforms in China. China Agricultural Economic Review, 3(2), 224-244. https://doi.org/10.1108/17561371111131335

Bissonnette, J.F. (2016). Is oil palm agribusiness a sustainable development option for Indonesia? A review of issues and options. Canadian Journal of Development Studies, 37(4), 446-465. https://doi.org/10.1080/02255189.2016.1202101

Caska, C., \& Indrawati, H. (2019). How to maintain sustainability of micro and small enterprises of crispy oil palm mushroom: A case study in Riau Province. Journal of Science and Technology Policy Management, 10(2), 431456. https://doi.org/10.1108/JSTPM-01-2018-0005

Cano-Kollmann, M., Awate, S., Hannigan, T.J., \& Mudambi, R. (2018). Burying the hatchet for Catch-Up: open innovation among industry laggards in the automotive industry. California Management Review, 60(2), 17-42. https://doi.org/10.1177/0008125617742146

Courtois, P., \& Subervie, J. (2015). Farmer Bargaining Power and Market Information Services. American Journal of Agricultural Economics, 97(3), 953-977. https://doi.org/10.1093/ajae/aau051

Devaux, A., Torero, M., Donovan, J., \& Horton, D. (2018). Agricultural innovation and inclusive value-chain development: a review. Journal of Agribusiness in Developing and Emerging Economies, 8(1), 99-123. https://doi.org/10.1108/JADEE$\underline{06-2017-0065}$ 
Di-Pietro, A., Prencipe, A., \& Majchrzak, A. (2018),. Crowd equity investors: an underutilized asset for open innovation in startups. California Management Review, 60(2), 43-70. https://doi.org/10.1177/0008125617738260

Engotoit, B., Kituyi, G.M., \& Moya, M.B. (2016). Influence of performance expectancy on commercial farmers' intention to use mobile-based communication technologies for agricultural market information dissemination in Uganda. Journal of Systems and Information Technology, 18(4), 346-363. https://doi.org/10.1108/JSIT-06-2016-0037

Fu, W., Sun, S., \& Zhou, Z. (2011). Technical efficiency of food processing in China: the case of flour and rice processing. China Agricultural Economic Review, 3(3), 321-334. https://doi.org/10.1108/17561371111165761

Grashuis, J. (2018). A quantile regression analysis of farmer cooperative performance. Agricultural Finance Review, 78(1), 65-82. https://doi.org/10.1108/AFR-05-2017-0031

Geoghegan, C., Kinsella, A., \& O'Donoghue, C. (2017). Institutional drivers of land mobility: The impact of CAP rules and tax policy on land mobility incentives in Ireland. Agricultural Finance Review, 77(3), 376-392. https://doi.org/10.1108/AFR-12-2015-0056

Gras, C., \& Hernández, V., (2014). Agribusiness and large-scale farming: capitalist globalisation in Argentine agriculture. Canadian Journal of Development Studies, 35(3), 339-357. https://doi.org/10.1080/02255189.2014.933702

Gaudreau, M. (2019). State food security and people's food sovereignty: competing visions of agriculture in China. Canadian Journal of Development Studies, 40(1), 12-28. https://doi.org/10.1080/02255189.2017.1410470

Huang, Z., \& Liang, Q. (2018). Agricultural organizations and the role of farmer cooperatives in China since 1978: past and future. China Agricultural Economic Review, 10(1), 48-64. https://doi.org/10.1108/CAER-10-2017-0189

Hendriani, S. (2018). The role of cooperative development strategy to improving the success of village cooperative (KUD) in Riau Indonesia. International Journal of Law and Management, 60(1), 87-101. https://doi.org/10.1108/IJLMA-11-20160132

Iba, H., \& Lilavanichakul, A. (2020). Drivers for continued use of a direct marketing channel: evidence from Thai farmers. Journal of Agribusiness in Developing and Emerging Economies, Vol. ahead-of-print No. ahead-ofprint. https://doi.org/10.1108/JADEE-09-2020-0196

Indarti, S. (2018). The role of corporate social responsibility (CSR) toward the development micro and small and entrepreneurs using partnership and community development program (PKBL) in Pekanbaru. International Journal of Law and Management, 60(1), 79-86. https://doi.org/10.1108/IJLMA-12-2016-0167

Indrawati, H., Caska, \& Suarman. (2020). Barriers to technological innovations of SMEs: how to solve them?. International Journal of Innovation Science, 12(5), 545-564. https://doi.org/10.1108/IJIS-04-2020-0049

Ison, R.L., \& Ampt, R.R., (1992). Rapid rural appraisal: A participatory problem formulation method relevant to Australian agriculture, Agricultural Systems, 38(4), 363-386. https://doi.org/10.1016/0308-521X(92)90029-N

Kamaliah, K. (2020). Disclosure of corporate social responsibility (CSR) and its implications on company value as a result of the impact of corporate governance and profitability. International Journal of Law and Management, 62(4), 339354. https://doi.org/10.1108/IJLMA-08-2017-0197

Kireyenka, N. (2019). Agrarian Sector: Trends, Scenarios, Policy. Modeling Economic Growth in Contemporary Belarus, Emerald Publishing Limited, 129-146. https://doi.org/10.1108/978-1-83867-695-720191009

Lakitan, B. (2019). Research and technology development in Southeast Asian economies are drifting away from agriculture and farmers' needs. Journal of Science and Technology Policy Management, 10(1), $251-272$. https://doi.org/10.1108/JSTPM-11-2017-0061

Lahham, N. (2016). Using Agricultural By-Products in Egypt-Palm Residues Industry. Innovation Africa, Emerald Group Publishing Limited, 283-310. https://doi.org/10.1108/978-1-78560-311-220151006

Liu, D., \& Zeinaly, S. (2020). A new model for investigating the role of IT-based innovation in the pharmaceutical knowledge-sharing attitude: A study of marketing biotechnology firms. Kybernetes. https://doi.org/10.1108/K-07-20190505

Lichtenthaler, U. (2011). OI: past research, current debates, and future directions. Academy of Management Perspectives, 25(1), 75-93. https://doi.org/10.5465/amp.25.1.75

Li, L., Lin, J., Turel, O., Liu, P., \& Luo, X.(R). (2020). The impact of e-commerce capabilities on agricultural firms' performance gains: the mediating role of organizational agility. Industrial Management \& Data Systems, 120(7), 12651286. https://doi.org/10.1108/IMDS-08-2019-0421

Mustanir, A., Lubis, S., Barisan., (2017), Participatory Rural Appraisal in Deliberations of Development Planning. International Conference on Democracy, Accountability and Governance, 163, 316-319. https://doi.org/10.2991/icodag17.2017 .60

Mariyono, J., Waskito, J., Kuntariningsih, A., Gunistiyo, G., \& Sumarno, S. (2019). Distribution channels of vegetable industry in Indonesia: impact on business performance. International Journal of Productivity and Performance Management, 69(5), 963-987. https://doi.org/10.1108/IJPPM-11-2018-0382

Naknaen, P. (2017). Biologically active compounds released and extraction efficiency of cantaloupe juice treated with combination of Rapidase EX color and Accellerase. Nutrition \& Food Science, 47(5), 623-634. https://doi.org/10.1108/NFS12-2016-0193

Pehrsson, T. (2016). Is innovation research contingent on competitive context? A systematic review of research in the agriculture and forest industry. European Business Review, 38(2), 225-247. https://doi.org/10.1108/EBR-09-2015-0089

Parida, V., Westerberg, M., \& Frishammar, J. (2012),. Inbound OI activities in high-tech SMEs: the impact on innovation performance. Journal of Small Business Management, 50(2), 283-309. https://doi.org/10.1111/j.1540-627X.2012.00354.x 
Pereira, R.M., MacLennan, M.L.F., \& Tiago, E.F. (2020). Interorganizational cooperation and eco-innovation: a literature review. International Journal of Innovation Science, 12(5), 477-493. https://doi.org/10.1108/IJIS-01-2020-0008

Pigatto, G., Martinelli, R.R., Queiroz, T.R., \& Bánkuti, F.I. (2020). Competitiveness and social network of Brazilian fish farmers. Journal of Agribusiness in Developing and Emerging Economies, 10(2), 237252. https://doi.org/10.1108/JADEE-04-2019-0056

Syahza, A., Bakce, D., \& Asmit, B. (2018). Natural rubber institutional arrangement in efforts to accelerate rural economic development in the province of Riau. International Journal of Law and Management, 60(6), 15091521. https://doi.org/10.1108/IJLMA-10-2017-0257

Syahza, A. (2019). The potential of environmental impact as a result of the development of palm oil plantation. Management of Environmental Quality, 30(5), 1072-1094. https://doi.org/10.1108/MEQ-11-2018-0190

Syahza, A., \& Asmit, B. (2019). Regional economic empowerment through oil palm economic institutional development. Management of Environmental Quality, 30(6), 1256-1278. https://doi.org/10.1108/MEQ-02-2018-0036

Syahza, A ., Suwondo., Bakce, D., Nasrul, B., \& Mustofa, R., (2020a). Utilization of Peatlands Based on Local Wisdom and Community Welfare in Riau Province, Indonesia. International Journal of Sustainable Development and Planning, 15(7), 1119-1126. https://doi.org/10.18280/ijsdp.150716

Syahza, A., Irianti, M ., Suwondo., \& Nasrul, B. (2020b). What's Wrong with Palm Oil, Why is it Accused of Damaging the Environment? Journal of Physics: Conference Series. 1655(012134). http://doi.org/10.1088/1742-6596/1655/1/012134

Surya, B., Saleh, H., \& Hamsina, H. (2021). Rural Agribusiness-based Agropolitan Area Development and Environmental Management Sustainability: Regional Economic Growth Perspectives. International Journal of Energy Economics and Policy, 11(1), 142-157. https://doi.org/10.32479/ijeep.10184

Sandham, L., Chabalala, J.J., \& Spaling, H. (2019). Participatory Rural Appraisal Approaches for Public Participation in EIA: Lessons from South Africa. Land, 8(10), 1-16. https://doi.org/10.3390/land8100150

Syahza, A., \& Indrawati, H. (2010). Pemberdayaan Koperasi Berbasis Agribisnis di Daerah Pedesaan. Sosiohumaniora, 12(3), 207-220. https://doi.org/10.24198/sosiohumaniora.v12i3.11551

Shikur, Z.H. (2020). Agricultural policies, agricultural production and rural households' welfare in Ethiopia. Journal of Economic Structures, 9(50). https://doi.org/10.1186/s40008-020-00228-y

Sun, L., \& Li, X. (2019). Comparison analysis on the bilateral efforts of farmers and the third-party organization under multiple contract modes. Kybernetes, 48(5), 818-834. https://doi.org/10.1108/K-03-2018-0102

Sathapatyanon, J., Kuwornu, J.K.M., Shivakoti, G.P., Soni, P., Anal, A.K., \& Datta, A. (2018). The role of farmer organizations and networks in the rice supply chain in Thailand. Journal of Agribusiness in Developing and Emerging Economies, 8(3), 554-578. https://doi.org/10.1108/JADEE-01-2017-0016

Savitri, E., \& Syahza, A. (2019). Effect Of Human Capital And Competitive Strategies Against The Financial Performance Of Small And Medium Enterprises, International Journal of Scientific \& Technology Research, 8(04), 86-92. available at: $\underline{\text { http://www.ijstr.org/research-paper-publishing.php?month=apr2019 }}$

Savitri, E., Abdullah, N. H. N., Said, J., Syahza, A., \& Musfialdy. (2020). How supply chain moderates the relationship of entrepreneurial orientation, adaptability strategy and government interference with performance? International Journal of Supply Chain Management, 9(4), 355-362. https://ojs.excelingtech.co.uk/index.php/IJSCM/article/view/5263

Townsley, P. (1996). Rapid rural appraisal, participatory rural appraisal and aquaculture. FAO Fisheries Technical Paper. 358. 109. FAO, Rome. Available from: http://www.fao.org/3/w2352e/W2352E00.htm\#TOC

Uddin, M., \& Anjuman, N., (2013). Participatory rural appraisal approaches: an overview and an exemplary application of focus group discussion in climate change adaptation and mitigation strategies. International Journal of Agricultural Research, Innovation and Technology, 3(2), 72-78. https://doi.org/10.3329/ijarit.v3i2.17848

Van Hemert, P., Nijkamp, P., \& Masurel, E. (2013). From innovation to commercialization through networks and agglomerations: analysis of sources of innovation, innovation capabilities, and performance of Dutch SMEs. The Annals of Regional Science, 50(2), 425-452. https://doi.org/10.1007/s00168-012-0509-1

Veldkamp, A., Van Altvorst, A. C., Eweg, R., Jacobsen, E., Van Kleef, A., Van Latesteijn, H., ... \& Van Trijp, J. C. M. (2009). Triggering transitions towards sustainable development of the Dutch agricultural sector: TransForum's approach. Agronomy for sustainable development, 29(1), 87-96.

Velázquez, B., \& Buffaria, B. (2017). About farmers' bargaining power within the new CAP. Agricultural and Food Economics, 5(1), 1-13.

Wynarczyk, P., Piperopoulos, P., \& McAdam, M. (2013). OI in small and medium-sized enterprises: an overview. International Small Business Journal: Researching Entrepreneurship, 31(3), $240-255$. https://doi.org/10.1177/0266242612472214

Zinchuk, T., Kutsmus, N., Kovalchuk, O., Dankevych, V., \& Usiuk, T. (2017). Institutional Transformation of Ukraine's Agricultural Sector. Review of Economic Perspectives, 17(1), 57-80. https://doi.org/10.1515/revecp-2017-0003

Zhou, L., Wu, J., Mu, D., Wu, Y., \& Gu, Z. (2016). Construction Innovation of Urban Green Logistics Centers for Agricultural Products. Open House International, 14(3), 26-31. https://doi.org/10.1108/OHI-03-2016-B0004 
(C) 2021 by the authors; licensee Growing Science, Canada. This is an open access article distributed under the terms and conditions of the Creative Commons Attribution (CC-BY) license (http://creativecommons.org/licenses/by/4.0/). 